\title{
Land, song, constitution: exploring expressions of ancestral agency, intercultural diplomacy and family legacy in the music of Yothu Yindi with Mandawuy Yunupinu ${ }^{1}$
}

\author{
A ARON CORN \\ Pacific \& Regional Archive for Digital Sources in Endangered Cultures, F12 - Transient, \\ The University of Sydney, NSW 2006, Australia \\ E-mail:aaron.corn@arts.usyd.edu.au
}

\begin{abstract}
Yothu Yindi stands as one of Australia's most celebrated popular bands, and in the early 1990s became renowned worldwide for its innovative blend of rock and indigenous performance traditions. The band's lead singer and composer, Mandawuy Yunupinu, was one of the first university-trained Yolyu educators from remote Arnhem Land, and an influential exponent of bicultural education within local indigenous schools. This article draws on my comprehensive interview with Yunupinu for an opening keynote address to the Music and Social Justice Conference in Sydney on 28 September 2005. It offers new insights into the traditional values and local history of intercultural relations on the Gove Peninsula that shaped his outlook as a Yolyu educator, and simultaneously informed his work through Yothu Yindi as an ambassador for indigenous cultural survival in Australia. It also demonstrates how Mandawuy's personal history and his call for a constitutional treaty with indigenous Australians are further grounded in the inter-generational struggle for justice over the mining of their hereditary lands. The article's ultimate goal is to identify traditional Yolnu meanings in Yothu Yindi's repertoire, and in doing so, generate new understanding of Yunupinu's agency as a prominent intermediary of contemporary Yolnu culture and intercultural politics.
\end{abstract}

\section{Introduction}

Yothu Yindi is one of Australia's most celebrated popular bands. Its innovative blend of rock and Yolnu performance traditions from northeast Arnhem Land (see Figure 1) has spawned six original albums (1989, 1991, 1993, 1996, 1999, 2000b) and thirteen music videos (1992a, 2000a). ${ }^{2}$ The band's philanthropic arm, the Yothu Yindi Foundation (YYF), has also produced six albums of traditional music from Arnhem Land (YYF 2001-2003), the motion picture Yolvu Boy (Johnson [dir.] 2000) and the annual Garma Festival at Gulkula (YYF 2006). 


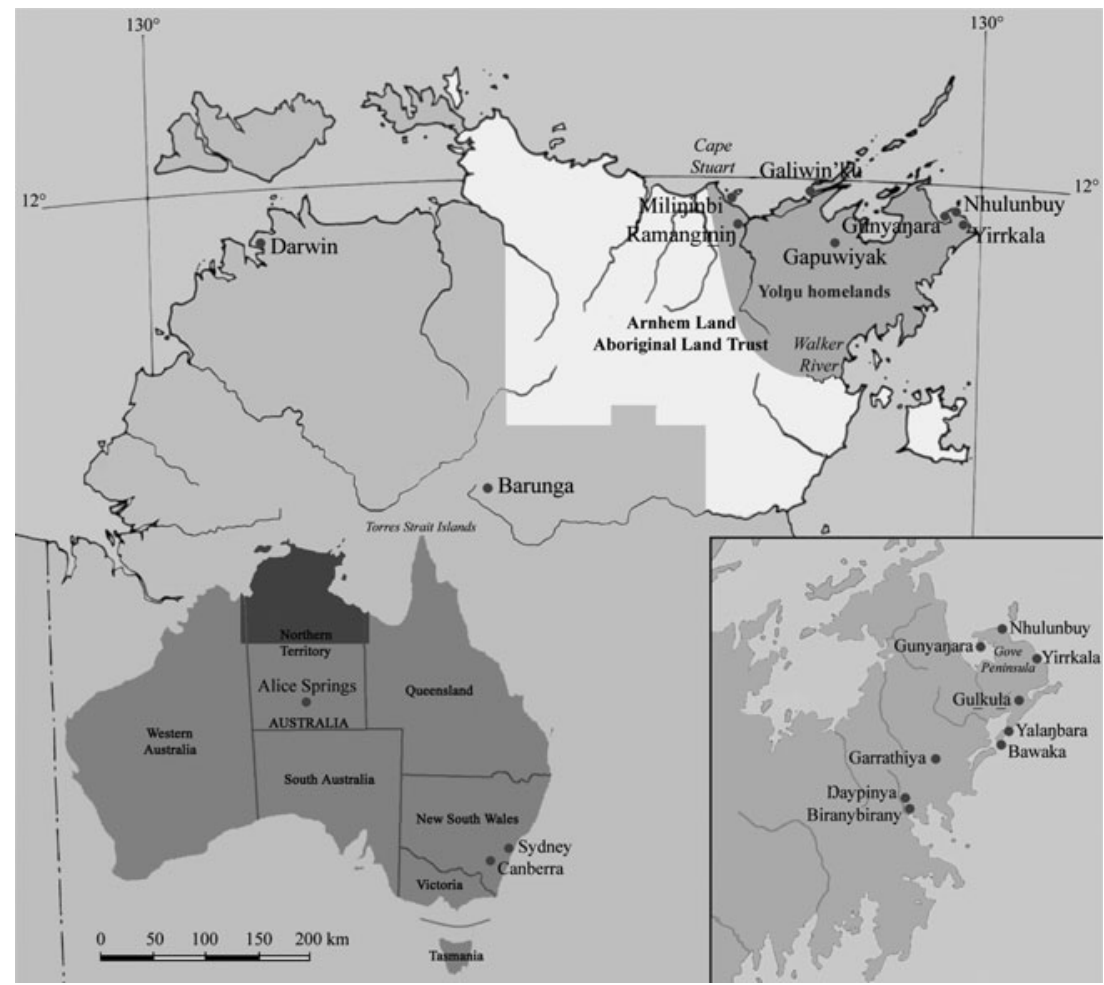

Figure 1. Locations within the Yolnu homelands, Arnhem Land and Australia.

Formed in Darwin in 1986, Yothu Yindi was founded by three Yolnu men from Yirrkala on the Gove Peninsula. Singer/guitarist Mandawuy Yunupinu, born 1956, became the band's primary songwriter. Witiyana Marika was then a purely traditional performer who sang and played bilma ('paired sticks'), while the late Milkaynu Munungurr was a traditional player of yidaki ('didjeridu'). ${ }^{3}$ Mandawuy had also forged strong friendships with a second trio of rock musicians known in Darwin as the Swamp Jockeys, bassist Stu Kellaway, guitarist Cal Williams and drummer Andy Beletty, who completed Yothu Yindi's original complement. The sounds they created together were built on an unprecedented syncretism of Yolnu performance traditions and global popular styles. Mandawuy's older brother, Galarrwuy Yunupinu, also contributed his skills as a traditional singer to the band's studio recordings, and created traditional artwork for each of its albums. Other significant members of Yothu Yindi have since included Indigenous singer Jodie Cockatoo, Yolnu multi-instrumentalist Gurrumul Yunupinu, Papuan drummer Ben Hakalitz, Papuan keyboardist Buruka Tau-Matagu, keyboardist Matthew Cunliffe, and Yolnu yidaki players Gapanbulu Yunupinu and Yomunu Yunupinu. At the peak of its popularity in the early 1990s, Yothu Yindi's chart success was unprecedented by any other band with indigenous Australian roots. In 1991, 'Treaty' (1991, tr. 2) became the first song with lyrics in any Australian language to chart anywhere. Worldwide multi-platinum sales ensued, as did a swathe of awards from MTV, the Australian Record Industry Association (ARIA), the Australasian Performing Right Association (APRA) and Australia's Human Rights 
and Equal Opportunity Commission (HREOC). 'Djäpana: Sunset Dreaming' (1991, tr. 3), a second song with lyrics in Yolnu-Matha, also charted well. With the announcement of Mandawuy Yunupinu as the 1992 Australian of the Year, the band's place in Australian history was sealed. Further recognition for Mandawuy came with an honorary doctorate in education from the Queensland University of Technology in 1998, and the Jimmy Little Deadly Award for Lifetime Achievement in Aboriginal and Torres Strait Islander Music in 2004.

Initial scholarship into Yothu Yindi focused on the roles of the entertainment and media industries in obscuring the politics behind 'Treaty'. The popularity of this song had initially been stimulated by an unauthorised dance remix (1992b, tr. 15) which stripped away all but three lines of its original English lyrics (Hayward [ed.] 1992, pp. 169-70; Hayward 1993; Mitchell 1992, 1993a, 1993b; Nicol 1993). Following studies aptly located the band's indigenous roots in Yolnu culture, and identified ganma ('converging currents') and yothu-yindi ('child-mother') as significant traditional themes both in its creative work and in Mandawuy's parallel career as a Yolnu educator (Neuenfeldt 1993; Stubington and Dunbar-Hall 1994; Magowan 1996, pp. 147-52; Dunbar-Hall 1997, pp. 39-42; Dunbar-Hall and Gibson 2004, pp. 198-208).

While Mandawuy offered his own thoughts on these themes in the 1993 Boyer Lecture (Yunupinu 1994), there nonetheless remained many unanswered questions about Yothu Yindi's role as an intermediary of Yolnu cultural life and indigenous political aspirations. It was unknown why Mandawuy started composing original rock songs with materials drawn from Yolnu tradition, or what he had hoped this innovation would achieve. Amid the sketchy inaccuracies of the band's album notes, it was also uncertain which specific traditional song repertoires had been worked into the band's music, or how their incorporation was aligned with Yolnu traditions for managing such hereditary properties. That the immediate family of the band's Yolnu founders had been engaged in a protracted struggle against the mining of their homelands on the Gove Peninsula since 1963 was another crucial factor that was absent from discussion of its creativity.

This article addresses these concerns by drawing on my keynote address with Mandawuy Yunupinu to the Annual Conference of the Musicological Society of Australia at the University of Sydney in 2005, which charted the traditional values, family history and compositional intent behind Yothu Yindi's music (Yunupinu and Corn 2005). The article is also grounded in my close collaborations with the band to chronicle its history and repertoire, and to determine how its creative approaches both reflect and extend traditional expressions of Yolnu sovereignty and culture (Corn with Yunupinu 2001, 2005; Corn with Yunupinu, Kellaway and Marika 2005; Corn with Yunupinu and Marika 2005). It is further contextualised within an extensive body of contemporary ethnographic research into Yolnu culture and music (Williams 1986; Morphy 1991, 2008; Knopoff 1992; Keen 1994, 2000; McIntosh 1994, 1996, 1997, 2000; Magowan 1994, 2007; Dunlop [dir.] 1970-1996; Cooke [ed.] 1996; Neuenfeldt [ed.] 1997, pp. 39-88; Tamisari 1998, 2000; Toner 2000; Corn with Gumbula 2003, 2005; Corn 2003, 2005, 2007; Corn and Gumbula 2004, 2006, 2007; Magowan and Neuenfeldt [eds] 2005, pp. 29-45, 57-95; Deger 2006; Stubington 2007).

Through intercultural ethnographic dialogues with Yolnu musicians, my approach has been to delve beyond the popular notions of 'dreamings', 'solo didjeridus', 'corroborees' and 'songlines' that have been internationalised as icons of 
indigenous Australia (Williams 1986, p. 25; Corn 2003). My goal in the article is to identify ethnocentric meanings in the music of Yothu Yindi that are readily apparent to local Yolnu audiences but obscure to others, and in doing so, to generate new understanding of Mandawuy Yunupinu's agency as a leading intermediary of contemporary Yolnu culture and political aspirations.

\section{Singing children of the earth}

The Yolnu (literally 'person', 'human') are the indigenous occupants and hereditary owners of northeast Arnhem Land in Australia's Northern Territory (NT). There are approximately 7000 Yolyu Australians whose remote homelands extend from the Gove Peninsula in the far northeast, west to Cape Stuart and southwest to Walker River. Four of the seven towns in this region, Milininbi, Yirrkala, Galiwin'ku and Ramanginin, were founded by the Methodist Overseas Mission between 1922 and 1973. Yothu Yindi's home town on the Gove Peninsula, Yirrkala, was founded as the second of these in 1934 (Horton [ed.] 1994, pp. 1,292-3; Corn and Gumbula 2006, p. 173). Gapuwiyak and Gunyanara were established by Yolnu families as respective satellites of Galiwin'ku and Yirrkala in the 1980s, while the mining town of Nhulunbuy was developed against Yolnu wishes near Yirrkala by the NABALCO corporation in 1967.

Yolnu society is an expansive network of some sixty patrifilial groups (literally, 'groups') (Zorc 1996; Bagshaw 1998, pp. 155-73). Membership in each mala is agnatic with hereditary ownership of each Yolnu group's country and other property passing from father to child in perpetuity. Mandawuy Yunupinu was born into the Gumatj mala, while Witiyana Marika and Milkaynu Munungurr were respectively born into the Rirratjinu mala and the Djapu' mala.

The Yolnu collectively speak a cluster of seven Australian languages known as Yolnu-Matha (literally 'human speech'). However, beyond everyday usage, each group possesses a discrete lexicon of esoteric yäku ('names') which, in formal usage, differentiates the matha ('speech') of one mala from another. Standing as constitutional evidence of this ownership, these lexicons of esoteric yäku are the most

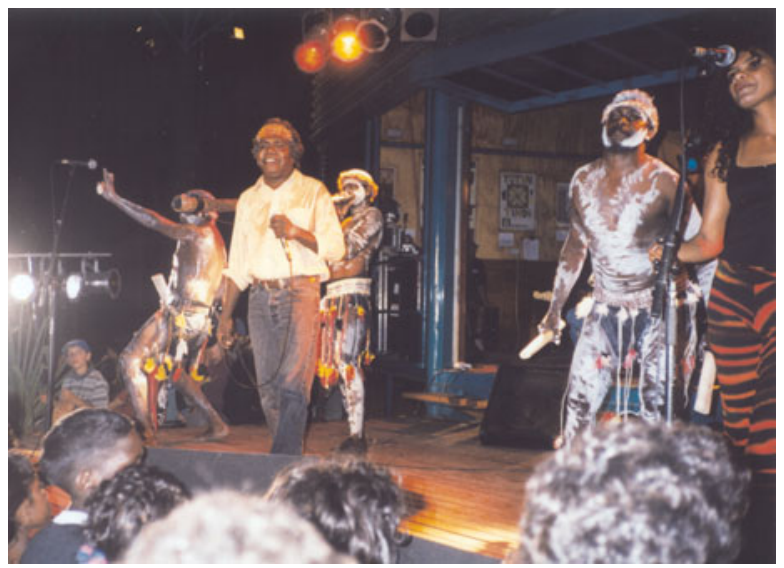

Figure 2. Yothu Yindi performs to open the Yirrna Music Development Centre on the Gumatj homeland of Gunyanara (Aaron Corn, 1999). 
valuable traditional asset any mala can possess other than country itself. Each mala owns at least one wäna ('country', 'homeland') incorporating all lands, waters and natural resources therein, and an incumbent canon of hereditary yäku ('names'), manikay ('songs'), bujgul ('dances') and miny'tji ('designs'). 'So axiomatic' is this relationship for Yolnu 'that people without land are people without identity' (Williams 1986, p. 232).

Yolnu have inhabited northeast Arnhem Land for countless millennia, and maintain hereditary knowledge of maritime sites known to have been above sea level some 10,000 years ago (Yunupinu and Dhamarrandji 1997; Buku-Larrngay Mulka Centre 1999; Horton [ed.] 1994, p. 201). They trace their ultimate descent from metaphysical wayarr ('ancestral progenitors') who originally shaped, named and populated the Yolnu homelands, and are believed to remain sentient and everpresent therein (Williams 1986, pp. 42-3; Gondarra 2001, pp. 15-20; Corn and Gumbula 2004, pp. 101-16). It is by virtue of this birthright, passed from father to child through each generation of each mala, that all Yolnu see themselves as both wäna-wataju ('country-holders') and rom-wataju ('law-holders').

The hereditary canons of names, songs, dances and designs bestowed by wajarr with the homelands are central to Yolnu identity and spirituality. They provide a highly durable ceremonial framework for practising Yolnu rom ('law', 'culture', 'correct practice', 'the way'), and also constitute an esoteric body of Yolnu knowledge known as madayin. Madayin describes the 'beauty' of all creation and the 'nature' of everything in it (Williams 1986, p. 29; Keen 1994, pp. 137-40; Gondarra 2001, p. 19). Its descriptions are both qualitative and exquisitely cryptic as is evident in traditional manikay series where yäku are used as a non-narrative lyrical resource (Williams 1986, p. 42; Keen 1994, p. 239; Corn and Gumbula 2007, pp. 120-2).

Only madayin of the garma ('open') and dhuni' ('sheltered') classes are performed in public contexts, while the deepest esoterica of the järra' ('restricted') class is conventionally revealed only to initiated men in seclusion (Keen 1994, p. 143). ${ }^{4}$ The garma madayin owned by each mala are organised in distinct strings of subjects that recount the species and ecologies observed by wayarr as they founded the Yolnu homelands. An individual subject can be shared by multiple mala. But for each individual subject, there still exists a string of several sacred names that is unique to each mala (Williams 1986, pp. 40-5). Canons of garma madayin always refer obliquely to details of ancestral characteristics and deeds recorded in the deeper dhuni' and närra' classes. Yolnu liken this relationship between the public and the restricted to a tree and its subterranean roots. Though unseen, a tree's roots are embedded in the same earth as the wayarr themselves (Keen 1994, p. 169).

Access to use and understanding of a group's hereditary names, songs, dances and designs is regulated by qualified ceremonial leaders who are known as the

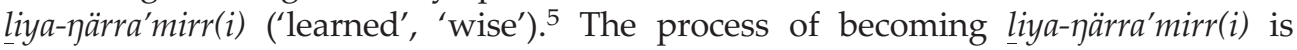
said to be a long and arduous one of attaining a demonstrable knowledge of all requisite madayin, and through this observance of ancestral law, accruing sufficient märr ('inner strength', 'ancestral power', 'spiritual health') (Keen 1994, pp. 94-5). Yolnu believe that the wayarr who remain sentient and ever-present in country can sense the märr of their living kin. They will render their homelands safe and abundant for those who can be recognised as gurrutu ('kin', 'family'), and similarly work to repel and poison intruders (Williams 1986, pp. 85; Tamisari 1998, pp. 25667). Following ancestral precedent through the observance of one's hereditary madayin is therefore considered a high virtue among Yolnu (Keen 1994, p. 149). 
Despite the intercultural syncretism of Yothu Yindi's music, this classical Yolnu worldview is seeded throughout its repertoire. The song 'Baywara' (1993, tr. 4), for example, clearly addresses the intimate relationships between country, ancestors and law in Yolnu epistemology. Its verses and bridge describe the progenitorial journey of Baywara, the wayarr 'Olive Python', to Jaypinya. This homeland is owned by the Gälpu mala to which Mandawuy's late mother was born. The lyrics 'She walked with the law in her hands, singing children of the earth' (verse 1) describe how Baywara sang the Gälpu mala into being at Jaypinya as she embedded her law and her sentience deep into the earth there. In the chorus, Mandawuy identifies her as 'Maker of the Land, Maker of the Song, Maker of the Constitution'.

Land, song and constitution are all integral; all one. You can't isolate one from the other. It's all interwoven very tightly and you can't separate them. That is written in the bark paintings; in the scrolls of the log coffins; in the songs. No matter what their language in Arnhem Land, everyone practises that. Even down in central Australia where they practise the boomerang, they talk about the same thing. It's the constitution. It's the law. It's the basis of where we come from. If you've ever been exposed to those big ceremonies, you see people dancing whether they're Shark people or Stingray people; whether they're Bäru ['Saltwater Crocodile'], the Maralitja ['Saltwater Crocodile'] man. Maralitja discovered fire in the beginning, so when you're dancing Bäru, you become transformed into Maralitja. And that's when you say 'I'm the Maralitja. I own the land. I own that philosophy. I own that knowledge. I have a right to that land and you can't take that away from me'. Other groups are the same. When people dance Shark, they're transformed into the Shark ancestor, or the Stingray or whatever it may be. That's how one becomes transformed into something they want to show; they want to tell in that most classical way. The classical way of making their point known is by doing it in unity and strength with one's own mala and, of course, the yothu-yindi ['child-mother'] balance between mala is always there in that strength and unity. We are still doing this regardless of our laws having been rejected and trivialised. We don't care. We keep going because it's important to pass on this law to the next generation so it strengthens our identity as a first-nations people of this country. (Yunupinu from Yunupinu and Corn 2005)

The music video for 'Tribal Voice' (1992a, tr. 6), a song from Yothu Yindi's second album (1991, tr. 7), exemplifies the intensity with which Yolnu realise ancestral identities through ceremonial performance. It features a genuine dhapi ceremony for male initiation by 'circumcision'. Mandawuy dances Gapirri ('Stingray') over the three boy initiates, while his older brother, Galarrwuy, sings manikay and paints deeply sacred designs on their bodies. As he dances, Mandawuy fixes a piercing forward gaze and clutches a deeply sacred Gumatj bathi ('basket') between his teeth. Baskets of this kind are dhuni', and stand as the most sacred emblems of wajarr authority that can be displayed in any public context. The bathi bears a pair of long orangefeathered tassels and an elongated diamond motif representing the Gumatj wayarr Maralitja ('Saltwater Crocodile'). Such ceremonial gakal ('displays') of ancestral power are also dhuni'. They mirror the fierce power of the wayarr and the gravity of ceremonial acts undertaken in their name (Morphy 1991, p. 263). As the 'Tribal Voice' clip ends, the boy initiates stand ready with the Gumatj elder Djana Yunupinu. Sacred tassles of orange parrot feathers adorn their heads, arms and waists, with painted heads and torsos completing their otherworldly appearance.

The boy standing camera left, Yomunu Yunupinu, would come to play yidaki for Yothu Yindi in the mid-1990s. But here in ceremony, the metaphysical nature of being in all Yolnu is made plain. Not only are the Yolnu the direct descendants of the original wajarr, they are also mirrored physical consubstantiations of the original wayarr presences that remain eternal and sentient in country (Williams 1986, pp. 23-4). 
'Tribal Voice' stands as Yothu Yindi's response to the lingering influence of Christianity in Yolnu lifestyles following decades of local administration under statesanctioned missions. The early Methodist missionaries in northeast Arnhem Land had abandoned their failing attempts to quell Yolnu traditions in 1926, and instead established an enduring spiritual and cultural dialogue that respected both Yolnu and Christian perspectives. Yet the withdrawal of the Methodists Overseas Mission from local government in the 1970s left room for a new brand of Christianity to sweep across Arnhem Land in the decade that followed. Owing much to US evangelism, it insisted on the abandonment of Yolnu traditions in favour of an exclusive Christian practice. Mandawuy was deeply concerned.

People here were strongly into the church. The whole place was saturated and there seemed no way out. It was like every second man and his dog was into it. My way of rejecting this was to challenge them by saying, 'Hey, our tribal voice is going to be here forever. How about coming down to earth and thinking about where your feet are entrenched; where your reality lies?' 'Tribal Voice' is about that struggle for recognition of our religious freedom and, of course, our freedom of speech. Don't throw it away and go for something else. (Yunupinu from Yunupinu and Corn 2005)

'Tribal Voice' was therefore conceived as a stirring rock anthem for Yolnu religious freedom and cultural survival. The song's chorus alludes to the global diversity of human religions, and echoes the activist expression of 'Get Up, Stand Up' by the Wailers (1973, tr. 1) (see Example 1). Mandawuy urges audiences to listen to their 'tribal voice', and later in the song's coda, he levels this appeal directly at the Yolnu mala who own homelands on the Gove Peninsula: Gumatj, Rirratjinu, Wangurri, Djapu', Dhalwayu, Dätiwuy, Mangalili and Gälpu (Dunbar-Hall 1997, p. 46). As backing singers repeat the hook 'You'd better listen to your tribal voice', Mandawuy shouts each of their names in turn over the word 'tribal' (see Example 2). With the lyrics 'Come now the sprits of my ancestors who have just gone before into the future of another day' in verse 3, Mandawuy evokes a central Yolnu belief: the cyclical passage
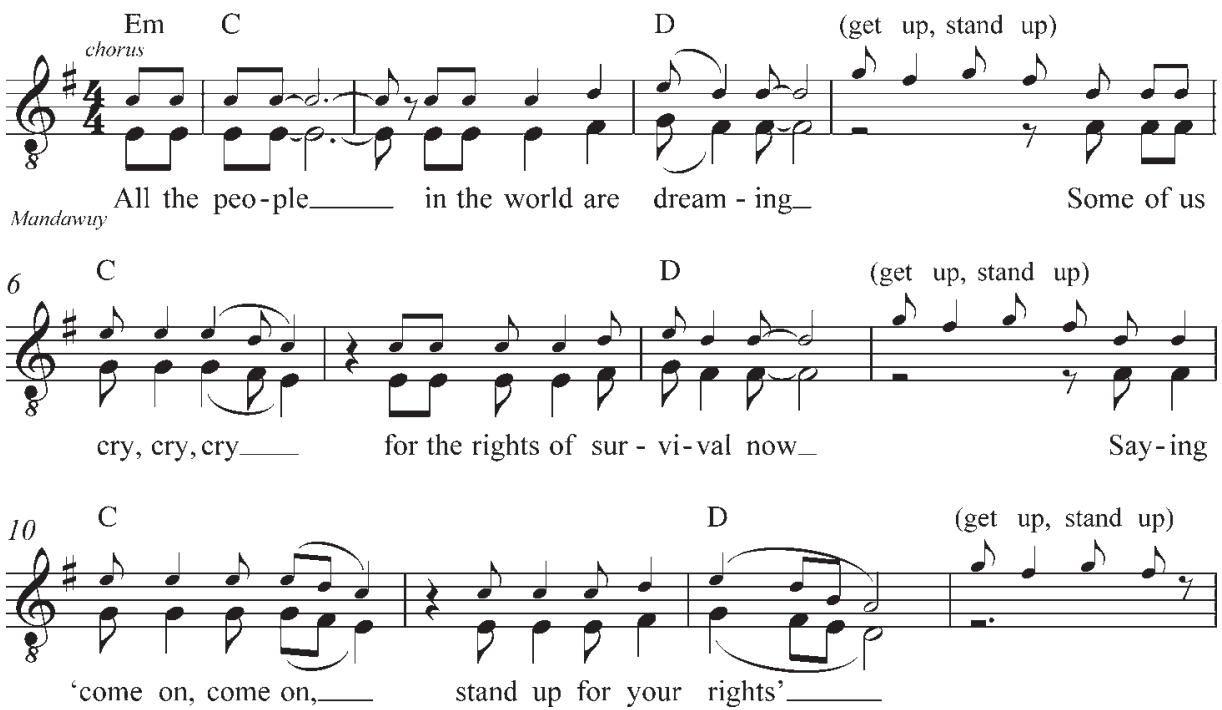

Example 1. Opening of the chorus of 'Tribal Voice' (Yothu Yindi 1991, tr. 7). 
of birrimbirr ('souls') through the physical and metaphysical planes of reality, from birth to death to rebirth, in an endless loop (Berndt and Berndt 1988, p. 213). In the spoken lyrics of the song's bridge, 'Yaka menguja nhujuway rom; dhuwala bujgul gakal likan', he also refers to the Stingray gakal he dances in the music video. While this statement has no direct English equivalent, it can be loosely translated from Yolnu-Matha as 'Do not forget your law; this ceremonial display of ancestral power' ${ }^{6}$

\section{To a homeland far away}

Before Yothu Yindi's ascent, never had sounds, images and ideas so sacred to the Yolnu been presented through an idiom so seemingly profane as rock. The band's rise to fame in the early 1990s was unarguably buoyed by its exotic appeal amid the growing global market for World Music. Commercial success was nonetheless far from the local and personal concerns that inspired Mandawuy's songwriting. His intrepid synthesis of rock and traditional Yolnu manikay developed in response to the entrenchment of Anglo-colonial influences in 1980s Arnhem Land. While the Methodist Overseas Mission had long been committed to working with Yolnu in both English and Yolnu-Matha, English was the only official language of the NT government agencies that, in the 1970s, had assumed their administrative and service roles. It was rapidly becoming impossible in Arnhem Land to buy groceries, book travel, access public services, find medical treatment or have a bank account without a working knowledge of English. English was also the only formal language of instruction in local schools, and now found even greater exposure among local youths amid the introduction to Arnhem Land of televisions, video players and portable stereos.

Yolnu of Mandawuy's generation had come through the mission era with their traditional knowledge largely intact. But now, it fell to them to ensure that these old ways were not swept away in a torrent of the new. As a senior Yolnu educator in an Arnhem Land school, Mandawuy knew that something radical needed to be done. His songwriting became his vehicle for shaping and theorising his ideas about new ways of schooling Yolnu children bi-culturally.
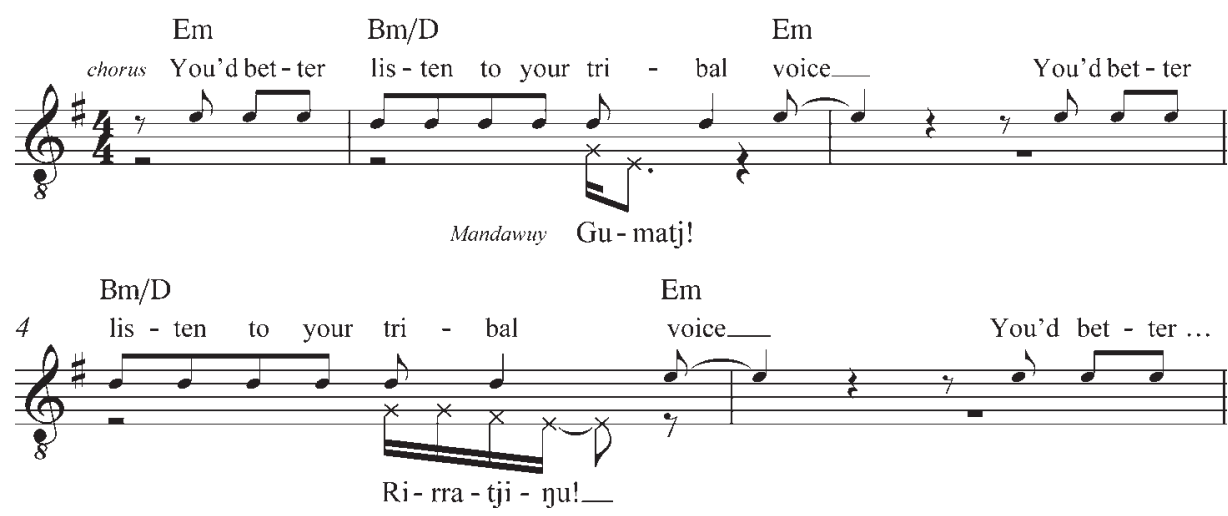

Example 2. The first two Yolnu mala names shouted by Mandawuy Yunupinu in the coda of 'Tribal Voice' (Yothu Yindi 1991, tr. 7). 
It was with his very first original song of 1983, 'Djäpana: Sunset Dreaming' (Yothu Yindi 1989, tr. 5), that Mandawuy began to explore the potential of blending manikay and rock. With most of its lyrics in English, this initial arrangement of 'Djäpana: Sunset Dreaming' sounded like a fairly conventional rock song. However, in drawing on themes and lyrics from the hereditary Gumatj manikay of Mandawuy's own mala, it was an unprecedented step nonetheless. Mandawuy wanted the song to express his warwu ('sorrow', 'homesickness', 'worry') for the young family he had left behind in Yirrkala while he worked in Galiwin'ku as the Assistant Principal of Shepherdson College. To capture this emotion, he turned to the subject of djäpana ('coral sunset') from the manikay series for the Gumatj homeland of Bawaka which recounts the ancestral trespasses of foreign marauders known only as the Bayini (Mountford 1956, pp. 333-8). In the hull of their boat, the Bayini had captured a beautiful woman called Djotarra, and when they finally sailed from Bawaka into the beautiful coral sunset, their vessel struck a rock in the shallow coastal waters drowning all aboard. In their traditional manikay setting, the lyrics selected by Mandawuy for the Chorus of 'Djäpana: Sunset Dreaming' express warwu for Djotarra's loss: 'Wo djäpana, wo warwu, wo rrämani, wo galajgarri' which can be translated as 'Oh coral sunset, oh sorrow, oh coral sunset clouds, oh coral sunset'. It is no coincidence that the song's third verse also mentions the Balanda ('Euro-Australians'), who in the twentieth century, intruded on Gumatj lands not to maraud, but to mine.

One evening after work, I was sitting with a friend of mine. I had a guitar and I was feeling sad for my family. My family didn't come with me at that time. They came afterwards; maybe two months after I was there on my own. I was sitting. I was thinking. I was worrying about my family and it was sundown. I was thinking about the lines in djäpana. I was thinking 'warwu'. I

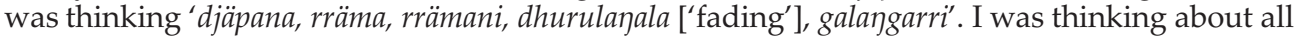
those names that make one sad and thinking about the family, because djäpana is about thinking back to your family. So I grabbed the guitar ... Djäpana ends a manikay series. It might take all day, and then at the end of the day, djäpana basically says goodbye. Goodbye to the day, to the people, and to friends, relatives and visitors from wherever they come. (Yunupinu from Yunupinu and Corn 2005)

'Djäpana: Sunset Dreaming' marked a new radical departure from Soft Sands' country and gospel idioms. It demonstrated how the rock idiom could be harnessed, as a wakinju ('kinless') resource that existed outside the strict protocols of Yolnu ownership, to incorporate themes and materials drawn directly from hereditary manikay as a means of conveying and contemporising durable ideas grounded in Yolnu tradition. It also followed and extended the Yolnu practice of composing noncanonical yuta ('new') manikay items in which traditional subjects are related to contemporary events, such as funerals and family separations, which evoke warwu as an emotional response (Knopoff 1992, pp. 144-50; Toner 2000, pp. 35-7). Though certainly unconventional, Mandawuy's approach nonetheless sought to satisfy the Yolnu ideals of following and honouring ancestral precedent.

Also at that time, there was a big movement in that most of the Yolnu in the bands were into gospel songs. There was a big gospel movement happening and my objective was to say, 'Now listen guys, there are other avenues to think about your culture'. My struggle was to preserve my culture and the way that I wanted to do that was to write a song with all those Western elements so I came up with the lines and the lyrics as a modern way of describing what I thought about in the traditional way. On the day after composing it, I went to the band Soft Sands and asked them if they could play this song using their equipment. I was able to feel 
it with the drums as well as the bass guitar, the lead guitar and rhythm guitar. I then worked out the chorus lines for it as time went on. We gave it a contemporary rock ' $n$ ' roll feel but still maintained that Yolnu side to it. (Yunupinu from Yunupinu and Corn 2005)

'Djäpana: Sunset Dreaming' became a template for how many Yothu Yindi songs would be composed. The band's songs would typically express Mandawuy's responses to topical issues through lyrical references to garma manikay subjects that alluded to their themes. As the Yothu Yindi style developed, direct musical quotations from manikay, in addition to lyrical ones, became its hallmark. For example, later recordings of 'Djäpana: Sunset Dreaming' (1991, tr. 3) augmented the song's traditional manikay content by quoting two entire stanzas, or gumurr (literally 'chests'), of the original djäpana over the band's throbbing four-beat (see Example 3).

This organic relationship between traditional manikay settings and the rock songs that they inspired is made even more apparent in the recording of 'Djäpana: Sunset Dreaming' on One Blood (Yothu Yindi 1999, tr. 8). On this fifth album, the song is preceded by an entirely traditional performance of 'Rräma (Coral Sunset Clouds)' (tr. 7) that is sung by Galarrwuy Yunupinu with bilma ('paired sticks') and yidaki ('didjeridu') accompaniment. Aural coherence between the traditional 'Rräma' and the rock song 'Djäpana: Sunset Dreaming' is established with the spoken vocables, 'Ap wi'. They are performed at the end of each stanza of 'Rräma' and are the first sounds of 'Djäpana: Sunset Dreaming' heard in the following track.
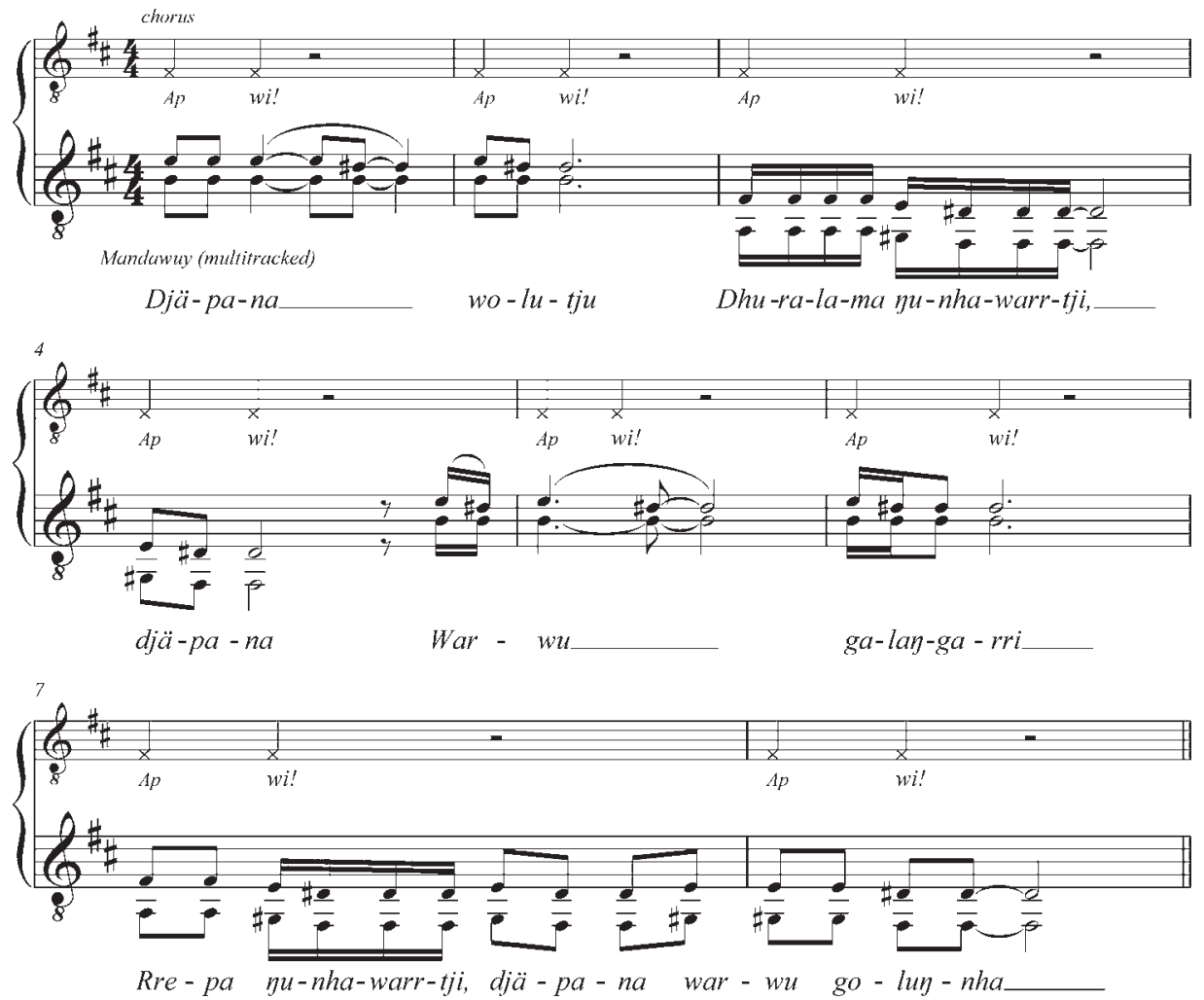

Example 3. Vocal parts of the first manikay section played in 'Djäpana: Sunset Dreaming' (Yothu Yindi 1991, tr. 3). 
Three other original songs on One Blood are similarly introduced by traditional manikay items from different manikay series. While Yothu Yindi's earlier albums are abundant with traditional manikay items, this particular configuration is most prevalent on One Blood. 'Laykarrambu (Male Red Kangaroo)' (tr. 1) precedes the titular 'One Blood' (tr. 2). Its distinctive bilma pattern (see Example 4) is heard again in the manikay bridges of 'One Blood' in which Mandawuy sings of the male red kangaroo's demise on the Gumatj homeland of Gulkula at the hands of the ancestral mokuy ('ghost') hunter, Ganbulapula. Both 'Laykarrambu' and the bridges of 'One Blood' share the terminal phrase, 'Wo duwitj, wo duwutj, wo duwitj', which describes the bloodied 'twitching' felled animal's carcass. 'Tears for Law: Garrathiya Run' (tr. 13) references the ancestral preparation of bread from the cycad palm and is introduced by 'Minamina (Cycad Nut Bread)' (tr. 12). Its melody uses the same pitch set as those found in the traditional melodic structure, or dämbu (literally 'head'), of 'Minamina' (see Example 5). Finally, the manikay lyrics of 'Nyinanyina (Anchovy)' (tr. 16) are again heard in the manikay bridge of the following rock song, 'Our Land' (tr. 17).

These are the only instances on Yothu Yindi's albums in which the organic relationships between traditional manikay settings and the rock songs they inspired are made so clear. Nonetheless, any original song incorporating thematic, lyrical or musical materials sourced from a traditional manikay item could potentially be introduced in this way. As Yolnu logic dictates, though the deep roots of a tree are buried and unseen, they are there nonetheless.

The traditional materials presented on Yothu Yindi's albums are largely drawn from manikay series inherited by Mandawuy and Galarrwuy through their Gumatj patrilineage or yarrata (literally 'string'). They include derivative original songs such as 'Maralitja: Crocodile Man' (1991, tr. 5), 'Tears for Law: Garrathiya Run' (1996, tr. 1), 'Yirrmala (Hull)' (1996, tr. 12), 'One Blood' (1999, tr. 2) and 'Fire' (2000B, tr. 2). 'Yolnu Woman' (1989, tr. 2) recounts a funeral ceremony that ended with 'the usual songs' (verse 3) on the Gumatj manikay subjects

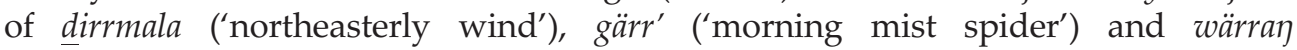
('dingo'). Brief performances of Gumatj manikay items in their traditional settings also feature on the band's albums. Sung by Galarrwuy, they include 'Gany'tjurr (White-Faced Heron)' (1993, tr. 15), 'Bäpan (Driftwood)' (1996, tr. 5), 'Lorrpu (Sulphur-Crested Cockatoo)' (1996, tr. 10), 'Laykarrambu (Male Red Kangaroo)' (1999, tr. 1), 'Minamina (Cycad Nut Bread)' (1999, tr. 12) and 'Bäru (Saltwater Crocodile)' (1999, tr. 14).

Early Yothu Yindi albums also feature Witiyana Marika singing traditional Rirratjinu manikay items on the subjects of 'Gudurrku (Brolga)' (1989, tr. 8), 'Dhum'thum (Agile Wallaby)' (1991, tr. 6), 'Yinydjapana (Dolphin)' (1991, tr. 10) and 'Milika (Diamond Fish)' (1993, tr. 9). However, 'Timeless Land' (1993, tr. 1) is the band's only original song to incorporate direct quotations from Rirratjinu

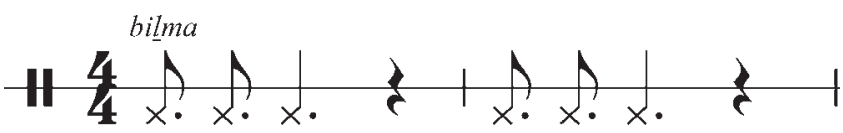

Example 4. The bilma pattern played throughout 'Laykarrambu' (Yothu Yindi 1999, tr. 1) and heard again in the manikay bridges of 'One Blood' (tr. 2). 


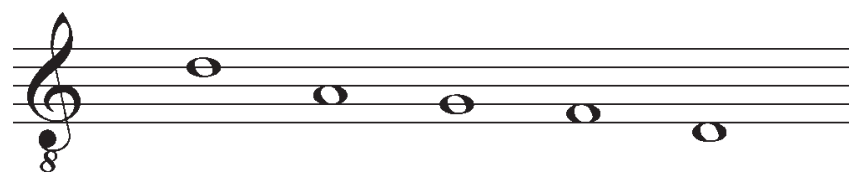

Example 5. The dämbu of 'Minamina' (Yothu Yindi 1999, tr. 12).

manikay. In the two manikay bridges of 'Timeless Land', Witiyana sings of the mulpiya' ('agile wallabies') who inhabit the rocky escarpment on the Rirratjinu homeland of Yalanbara. Later in the song's coda, he juxtaposes this against one of his mother's traditional manikay on the Gumatj subject of mambulmambul ('rare kangaroo flesh'), thereby evoking the yothu-yindi ('child-mother') balance among the band's members.

There are also several original Yothu Yindi that collectively cite Mandawuy's lineage from his Gälpu jändipulu ('mother's group'), and his Dhalwayu märipulu ('mother's mother's group') (see Table). Mandawuy's continuing relationship with his late parents is celebrated in 'Gapirri (Stingray)' (1991, tr. 13), which personifies his father as the Gumatj Stingray ancestor and his mother as the Gälpu wayarr, Baywara ('Olive Python'). Mandawuy's mother is also remembered in 'Dots on the Shells' (1993, tr. 13), yet 'Baywara' (1993, tr. 4) remains the only original Yothu Yindi song to quote Gälpu manikay. Its traditional manikay bridge cites the bonbarr ('lightening') spoken by Baywara as she founded the Gälpu homeland of Daypinya. The manikay of Mandawuy's Dhalwanu märipulu are similarly quoted in 'Honey: Birrkuda (Bee)' (1996, tr. 13) and 'Macassan Crew' (2000b, tr. 1).

An oblique reference to Mandawuy's late father's father, the prolific Gumatj leader known as Yunupinu, is found in 'Our Land' (1999, tr. 17) with its quotation of the traditional manikay 'Nyinanyina (Anchovy)' (1999, tr. 16). Yunupinu was renowned for having held leadership responsibilities for both the Gumatj mala and the Wangurri mala, and as a madayin subject held by both, nyinanyina represents this historical union (Williams 1986, p. 190). The barely perceptible rapidity with which these tiny fish dart about symbolises the deftness of Gumatj leaders as political negotiators.

Table. Yolvu mala referenced in Yothu Yindi's repertoire.

\begin{tabular}{|c|c|}
\hline \multirow{4}{*}{$\begin{array}{l}\text { Gumatj } \\
\text { Rirratjinu }\end{array}$} & Mandawuy Yunupinu's own நapawanditj ('spine-group') \\
\hline & The yapawanditj of Witiyana Marika \\
\hline & The wakupulu ('woman's child's group') of Mandawuy \\
\hline & The yändipulu ('mother's group') of Mandawuy's daughters \\
\hline Gälpu & The jändipulu of Mandawuy \\
\hline \multirow[t]{2}{*}{ Dhalwanu } & The märipulu ('mother's mother's group') of Mandawuy \\
\hline & $\begin{array}{l}\text { A yapapulu ('sister group') of the Manatja' mala, Mandawuy's daughters' märipulu, } \\
\text { which was massacred by pastoralists at the opening of the twentieth century } \\
\text { (Yothu Yindi 1996, cover notes and tr. 13) }\end{array}$ \\
\hline Wangurri & $\begin{array}{l}\text { A yapapulu of the Gumatj mala for which Mandawuy's märi'mu ('father's father'), } \\
\text { Yunupinu, held leadership responsibilities }\end{array}$ \\
\hline
\end{tabular}




\section{Living in the mainstream}

Mandawuy first set forth a response to the prevailing Anglocentrism of public schooling in Arnhem Land in 1986 in his third original song, 'Mainstream' (1989, tr. 1). By this time, he was in his final year of study towards a Bachelor of Arts in Education from Deakin University. The curriculum was dominated by a colonialist assumption that indigenous children were best served by a mainstream education with formal instruction in English, and this prompted Mandawuy to reconsider his own experiences of schooling under the Methodists.

Looking back now, I can see that the teachers probably saw things differently to me. Many of their demands were quite incomprehensible. They weren't just teaching me 'useful things'. They had a theory, an ideology. I see now that it was a curriculum driven by the ideology of assimilation. I marvel at the ways we knew how to resist it. I see now that a lot of what motivated those white teachers was the view that it was only when Yolnu stopped being Yolnu that we could be Australians. (Yunupinu 1994, p. 116)

Albeit predominantly in English, Mandawuy launched his counter-argument in a typically Yolnu fashion. He wrote a song about it. When asked to write an assignment on educational outcomes for indigenous school students, Mandawuy instead composed 'Mainstream' and submitted it for assessment. It was awarded a high distinction.

Again, on first hearing, 'Mainstream' sounds like an innocuous rock ballad. It nonetheless set forth the central tenant of Mandawuy's revolutionary ideas on bilingual and bicultural education in indigenous schools. 'Mainstream' asserted that Yolnu children should be entitled to learn all the necessary skills for participating in broader Australian society without having to relinquish their own traditions, and it sought to turn entrenched Anglocentric notions of what constituted a mainstream education upside down. The song's chorus contends that ancestral law forms the only 'mainstream' of thought in which Yolnu have been raised and educated for countless millennia, and its only Yolnu-Matha word, 'go' ('come'), beckons Yolnu to continue in this tradition. The passage of Mandawuy's own Gumatj traditions from father to child in perpetuity - from the original wayarr to his own children - is referenced in the first verse of 'Mainstream'. Here, gapu ('water') is evoked as the liminal medium through which souls migrate between the physical and metaphysical planes of reality (Berndt and Berndt 1988, p. 213). Thus, as Mandawuy sees his own daughters reflected 'in the water', he simultaneously hears the 'voices' of ancestral 'Yolnu heroes' (Yothu Yindi 1989, tr. 1, verse 1).

'Mainstream' was my first challenge to mainstream education. Here I was, for the first time, sitting equally with third year students in the university system. So for me, as I was one of only five indigenous students there, this was my way of saying, 'Listen, I can come in. I can sit. I can learn. But still, I have my own traditions which are equal to yours'. So this song is not about assimilation. It's about my law being as equal as yours. (Yunupinu from Yunupinu and Corn 2005)

Grounded in ideals of equality, balance, respect and dialogue between different peoples, Mandawuy's vision was for a school curriculum that incorporated formal instruction in both Yolnu-Matha and English through which Yolnu students would learn to be bicultural. To capture these ideals in 'Mainstream', he drew on traditional models for balance and cooperation between different mala which stem from the systemic diconstitutionality of Yolnu society (Corn and Gumbula 2006). 
All Yolnu mala are organised under two discrete yet interdependent constitutions of rom known as Dhuwa and Yirritja. Each mala is constituted as either Dhuwa or Yirritja, and this arrangement forms the primary balance of powers in Yolnu political life (Gondarra 2001, p. 19). The mala named in the coda of 'Tribal Voice' (Yothu Yindi 1991, tr. 7) are listed in an alternating order. Gumatj, Wangurri, Dhalwanu and Mangalili are Yirritja, while Rirratjinu, Djapu', Dätiwuy and Gälpu are Dhuwa.

Alignment with a constitution, like membership of a mala, is patrilineal, and Yolnu are only permitted to marry someone born into a mala of the opposite constitution. Therefore, while Mandawuy's daughters share his own Gumatj lineage under the Yirritja constitution, their mother is Rirratjinu under the Dhuwa constitution. Similarly, a mala can only ever succeed ownership in the hereditary property of another under the same constitution. The cross-constitutional relationship between waku ('woman's child') and nändi ('mother') is nonetheless fundamental to maintaining balance and order within Yolnu society. It is the duty of waku to support their jändipulu ('mother's group') by scrutinising all of their ceremonies and political dealings to ensure their legality (Morphy 1991, pp. 66-7).

Two distinct traditional models for balance and cooperation between different mala are referenced in 'Mainstream' to convey Mandawuy's ideal of biculturalism. The first, ganma ('converging currents'), is intra-constitutional, while the other, yothu-yindi ('child-mother'), is cross-constitutional (Neuenfeldt 1993; Yunupinu 1994; Stubington and Dunbar-Hall 1994; Magowan 1994).

Firstly, ganma symbolises the relationship between yapapulu ('sister groups') of equal social standing under the Yirritja constitution. This is a diplomatic relationship of respectful distance and recognition of each other's political independence (Morphy 1991, p. 70). Cooperation between yapapulu in mounting shared Yirritja ceremonies is likened to the meeting of independent currents, whether salt or fresh, in an estuary. The estuarine ganma site on the coastal Gumatj homeland of Biranybirany was a key inspiration for Mandawuy's ideas on biculturalism. Here, freshwater flows from the inland out into the sea. The point where it meets saltwater is marked by the production of djikungun ('yellow foam') on the estuary's surface, hence the reference to 'yellow foam floating down the river' in the first verse of 'Mainstream'. In this ganma model, independent currents can never assimilate each other, yet will always be productive in their interactions. The ganma site at Biranybirany is also significant to the Gumatj for its sacred association with gurtha ('fire'), and its symbolism of their historical accord with the Wangurri.

Ganma is a place where, when the water runs out, it's empty. There's no water and that ganma point is where fire is represented by the seaweed growing. It's considered a symbol of fire where the dugong eats and rolls on it. Ganma also connects us with the Wangurri mala, my yapapulu or 'sister group'. Our father's father, Yunupinu, had responsibilities for Gumatj and responsibilities for Wangurri. It's drawn from the very depth of our knowledge and practices that we consider as ritual between the mala. (Yunupinu from Yunupinu and Corn 2005)

Mandawuy's thinking on biculturalism was also inspired by the yothu-yindi relationship which promotes close familial cooperation between mala of different constitutions. In 'Mainstream', the lifelong bond between child and mother is therefore represented in the contrasting lyrical themes of the first and second verses. Mandawuy's description of his daughters and their Gumatj patrilineage in verse 1 is juxtaposed against the second verse's imagery of thunder rolling which is associated with their Rirratjinu ๆändipulu. 
So important was the yothu-yindi relationship to Mandawuy's thinking in 1986, that it became his band's name. After all, his two of his co-founders were his own sisters' children: his Rirratjinu waku, Witiyana Marika, and his Djapu' waku, Milkaynu Munungurr. Their relationships with Mandawuy came as consequences of the yothuyindi bridge between Dhuwa and Yirritja. The band also reflected in microcosm the ethos of biculturalism that Mandawuy sought to introduce into Yolnu school curriculum. From the beginning, its membership included both Yolnu and Balanda ('Anglo-Australian') musicians, and its music incorporated both Yolnu performance traditions and globalised popular styles. Like the graduates that Mandawuy hoped a bicultural education would produce, Yothu Yindi demonstrated how Yolnu could engage with the broader world, while simultaneously remaining true to core ancestral values. This was the goal of a bicultural education, and this is what Yothu Yindi hoped to inspire.

The ideas set forth in 'Mainstream' were highly influential and swiftly inspired new bicultural approaches to curriculum development in Yolnu schools (Yirrkala Community School Action Group 1988; Christie 1989; Marika, Jurruwutthun and White 1989; Harris 1990). Mandawuy became the first Yolnu Principal of the Yirrkala Community School in 1990, and continued to theorise ganma as a collaborative space where new dialogues between Yolnu and Balanda intellectual traditions could legitimately exist and generate new understandings. The hope of new understanding between Yolnu and Balanda is the final theme presented in the third verse and coda of 'Mainstream'. Here, Mandawuy envisions 'reflections in the water' of a nation in which 'black and white' Australians live, share and learn together.

A similar theme of unity between different peoples is presented in 'One Blood' (Yothu Yindi 1999, tr. 2) which Mandawuy composed in anticipation of the 2000 Olympic Games in Sydney. Here, a traditional Gumatj setting laykarrambu ('male red kangaroo') is quoted in the song's two manikay bridges. The swiftness of this animal symbolises the peak physical condition of Olympic athletes, while the blood shed from its speared carcass represents the 'one blood' that beats in the hearts of all humanity. The lyrics, 'one blood', are heard at the end terminal of each formal section. In the chorus, they are preceded by the Yolnu-Matha lyrics, 'Mittji mäypa, miny'tji gulku, bata'yunmirri, ganydjarr-nupan', can be translated as 'Different peoples, many colours, racing each other, racing'. 'Timeless Land' (Yothu Yindi 1993, tr. 1) reveals the traditional roots of Mandawuy's allusion to the blood of laykarrambu as the blood of all humanity. Its traditional manikay coda describes how the Gumatj will share the mambulmambul ('rare kangaroo flesh') that they hunt with the peoples of all mala. The coda of 'One Blood' (Yothu Yindi 1999, tr. 2) also refers to the pursuit of precious ancestral knowledge, which the Yolnu traditionally characterise as guku ('honey'). Here, Ganbulapula, the ancestral mokuy who hunts laykarrambu on the Gumatj homeland of Gulkula, searches for $g u k u$ in the forest canopy above.

\section{Written on a bark}

Yothu Yindi's quest to encourage better understanding between different peoples in Australia is grounded in the grave legacy of mining on the Gove Peninsula, and its devastating effect on Mandawuy, Witiyana and Milkaynu's family. The Australian government's refusal to recognise Yolnu sovereignty over this issue is referenced throughout the band's repertoire, and inspired the composition of its most famous song, 'Treaty' (1991, tr. 2). 
In 1963, the Australian government granted a bauxite lease over the lands surrounding Yirrkala to the mining company Pechiney. Hereditary Yolnu owners were locked out of all negotiations. Mandawuy's father, Mangurrawuy Yunupinu, was then a senior Gumatj elder at Yirrkala, and had recently finished collaborating with fifteen other elders to paint the 'Yirrkala Church Panels' (Marika et al. 19621963). Spanning two giant bark panels representing the Dhuwa and Yirritja constitutions, this extraordinary document was created as a symbol of contemporary Yolnu solidarity. The two panels respectively incorporated the most sacred hereditary designs of six Dhuwa mala and three Yirritja mala. They were initially hung on either side of the crucifix inside the Yirrkala Church to demonstrate the equality of the Christian and Yolnu faiths (Mundine 1999, pp. 24-5). Mandawuy was a young boy at the time of the panels' production, and Mangurrawuy cut fine hair from his head to make brushes for painting its Gumatj designs.

My father was kind in accepting the non-Aboriginal who people came to him. He also wanted to bring into the church his law, and I think I inherit that sense of balance from him. He wanted to give non-Aboriginal people, even the missionaries, a sense of 'Hey listen, we've been here a long time and this is what we know. This is our way of telling you that we go deeper, and our layers of knowledge go deeper than you thought'. His paintings on the right panel are of the saltwater crocodile, the Maralitja man, and the yellow ochre man, Wirrili, from Biranybirany, the same land where the saltwater crocodile discovered fire. He used my hair for that painting, so it's very significant and historic for me. (Yunupinu from Yunupinu and Corn 2005)

The newfound solidarity of the Yolnu elders at Yirrkala was soon tested when the lands to be mined were summarily excised from the Arnhem Land Aboriginal Reserve, and they acted swiftly to register an official protest in the form of the 'Yirrkala Petition to the House of Representatives' (Marika et al. 1963). Again spread across two painted bark panels representing the Dhuwa and Yirritja constitutions, this second document incorporated a statement in Yolnu-Matha and English that beseeched the Australian government to spare their lands. Known colloquially at the 'Yirrkala Bark Petition', it is now on permanent public display in Parliament House in Canberra, yet it did nothing to change the immediate fate of the Yirrkala community.

When NABALCO obtained the Pechiney bauxite lease in 1967, the nearby Rirratjinu homeland of Nhulunbuy was instantly bulldozed to make way for a residential mining town. The mine itself went into production in the following year. Heartbroken, the Yirrkala elders issued a writ through the Supreme Court of the NT in an attempt to halt all mining activities (Mundine 1999, p. 22). Their case, Milirrpum v. Nabalco (Australia 1968), was heard by Justice Blackburn. It probed the restricted depths of Yolnu rom and its provisions for property management among seven local mala.

I remember that time when my father gathered all the elders and they went out bush. They prepared for weeks before flying to Darwin, all the things one would want to think about in terms of law. These elders were there. They were serious about talking to the judge because they knew that they had to convince the Australian high courts. So they spent maybe two weeks in the bush doing what elders would do to initiate young men. In this case, they were preparing restricted things to show Blackburn. They took those things to court. And what did Blackburn do? (Yunupinu from Yunupinu and Corn 2005)

Mandawuy's father, Mangurrawuy Yunupinu, and Witiyana's father, Dadayna Marika, both gave evidence on the plaintiffs' behalf. Mandawuy's older brother, 
Galarrwuy, was also present throughout the proceedings as a court interpreter, and he witnessed the plaintiffs' eventual defeat in Canberra on 27 April 1971, when Justice Blackburn ruled that hereditary Yolnu land ownership had 'never formed any part of the law of any part of Australia' (Australia 1971, pp. 244-5). Further insult to Yolnu dignity came when Blackburn determined that the plaintiffs had not proven their descent from the indigenous people who had inhabited the Gove Peninsula when Captain Arthur Phillip claimed the Australian continent for the British Crown on 26 January 1788 (Australia 1971, p. 198).

That was the biggest disappointment. My father was devastated when we lost that court case, and I saw most of the elders, along with my father, saddened. We'll never forget that those aspects of our law, our strength and our unity were not seen as part of Australian culture, and the Australian way of life in the Yolnu way. (Yunupinu from Yunupinu and Corn 2005)

Blackburn's judgment (Australia 1971) is scathingly satirised by Galarrwuy in 'Luku-Wänawuy Manikay (Sovereignty Song) 1788' (Yothu Yindi 1989, tr. 15). Composed to coincide with Australia's 1988 bicentenary, the song parodies a federal parliament sitting. Its first three verses relate the strange tale of the Balanda, who claim to have owned the Yolnu homelands ever since 1788, when Captain Phillip planted a Union Jack at Sydney Cove in the name of George III. That this singular act of succession took place some 2,500 kilometres away from the Yolnu homelands, and 135 years before the first missionaries landed there was apparently of no consequence. In the four verses that follow, Galarrwuy asserts the continuation of Yolnu sovereignty under rom, and retorts that Phillip would have been hastily repelled had he landed at Yirrkala. The humour of 'Luku-Wänawuy Manikay 1788' is further underscored by an offbeat acoustic guitar accompaniment that is reminiscent of Anglo-Australian revivalist folksongs.

By 1988, Galarrwuy was in his third term as Chair of the Northern Land Council (NLC), which had been founded alongside the Central Land Council (CLC) in 1976 to represent indigenous land interests in the Northern Territory. Australia's bicentennial celebrations presented the NLC and CLC an opportunity to revisit Blackburn's judgement against the Yirrkala elders, and to reaffirm the collective sovereignty of indigenous Australians. Prime Minister Robert Hawke's visit to the Barunga Festival that year provided the setting. There, Hawke was presented a new document called the 'Barunga Statement' (Yunupinu et al. 1988), which called on the federal government to enter into a formal Treaty with indigenous Australians in recognition of the prior ownership, continuing occupation and sovereignty of their homelands, and as an affirmation of their human rights and freedoms. To demonstrate the solidarity of indigenous Northern Territorians in this request, the 'Barunga Statement' took the form a single typescript around which was painted Yolnu and central Australian designs.

Hawke's initial response to the 'Barunga Statement' was surprisingly positive, and he promised that its call for a Treaty would be fulfilled within the lifetime of his parliament (Aboriginal and Torres Strait Islander Commission 2001). However, this was not to be. By 1990, when Hawke's promise of a Treaty had all but faded from public consciousness, Yothu Yindi intervened. The band worked with Peter Garrett of Midnight Oil, the iconic Australian balladeer Paul Kelly, and indigenous reggae veteran Bart Willoughby to create a song that would recapture the public's imagination. ${ }^{7}$ Willoughby and Garrett in particular had been among the first 
musicians to sing out against the systemic injustices faced by indigenous Australians (No Fixed Address 1982; Midnight Oil 1986). The result of their collaboration was 'Treaty' (1991, tr. 2), and its Chorus was incisive: 'Treaty yeah, Treaty now'.

1988 was when Prime Minister Hawke came to Barunga and, at that Barunga Festival, he made a statement. He said there shall be a Treaty between Aboriginal Australia and white Australia. Everyone was really excited about it. 'Ah yeah, finally there'll be a Treaty.' Further down the track - 1988, 1989, 1990 - that's when I started to get suspicious about this Treaty. There was no action being taken. So I teamed up with Paul Kelly, Peter Garret and Bart Willoughby, a few Australian musicians, and we wrote the song 'Treaty'. It's a reflection on the Australian government at that time, and the Australian people for that matter. When is the Treaty? What is the Treaty? How is it going to take form, and in what shape will a Treaty come into being in Australia? We wrote that song 'Treaty' as a reminder to us all. (Yunupinu from Yunupinu and Corn 2005)

The first verse of this song recounts how Hawke's promise of a Treaty in 1988 was broadcast worldwide, but then disappeared 'just like writing in the sand'. The song's music video (1992a, tr. 1) presents corroborating evidence. It shows the completion of the 'Barunga Statement' at the Barunga Festival, news footage of Hawke's visit there, and the ravages of bauxite mining on the Gove Peninsula. The song's second verse contrasts Hawke's unfulfilled promise against the permanence of Yolnu rom. It asserts that the Yolnu never sold or ceded their 'priceless' homelands to the British Crown, and echoing 'Luku-Wänawuy Manikay 1788' (1989, tr. 15), declares that 'the planting of the Union Jack never changed our [Yolnu] law at all'. There is also a reference to ganma in this verse. Here, the unity that a Treaty would engender between indigenous and other Australians is described as 'two rivers' becoming 'one'. The traditional song quoted in the bridges of 'Treaty' is not of the manikay tradition, but of a style known as djatpanarri that dominated as a popular musical form at Yirrkala from the 1930s to the 1970s (Knopoff 1997, p. 603). Composed by the Gumatj singer Rrikin Burarrwaya in the 1950s, its presence here evokes nostalgia for Mandawuy's childhood years before the ravages of mining on the Gove Peninsula. The dämbu ('head') of this djatpanarri is repeated in the opening phrase of each verse in 'Treaty' (see Example 6) (Stubington and Dunbar-Hall 1994, pp. 252-3).

Many other Yothu Yindi songs also cite the legacy of mining on the Gove Peninsula. The opening lyrics of 'Our Generation' (1993, tr. 14) - 'someone in the city gets a piece of paper; someone in the bush holds the law in their hands' - address the ontological schism between Balanda law and Yolnu rom that coloured Blackburn's judgment. 'Baywara' (1993, tr. 4) and 'Gunitpirr Man' (1993, tr. 11) were both composed in memory of Witiyana's father, Dadayna Marika, who had given evidence for the plaintiffs. Mandawuy explains how the events surrounding his passing are referenced through the manikay quotation of bonbarr ('lightning') in 'Baywara'.

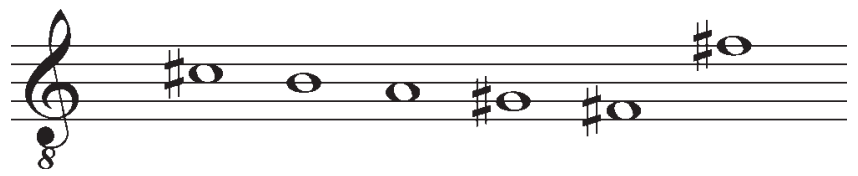

Example 6. The dämbu of the djatpanarri by Rrikin Burarrwaya quoted in 'Treaty' (Yothu Yindi 1991, tr. 2). 
'Baywara' is a special song because, in 1991, my uncle, who is considered to be the father of land rights, passed away. We were recording our second album, Tribal Voice, at that time and, when he passed away, we were at a mobile studio at Gunyanara. We were sitting outside that evening, and there was lightning in the sea and in the freshwater talking. Two snakes were talking to each other in the freshwater and the saltwater. That inspired me to write this song about Baywara as my uncle was a master of that philosophy. He taught much of how Yolnu are initiated with the Baywara philosophy so this song was specially written when he passed away. (Yunupinu from Yunupinu and Corn 2005)

'Homeland Movement' (1989, tr. 3) recounts how, after decades of mission life, Yolnu worked to establish outstations on their homelands in the aftermath of Blackburn's judgment (Australia 1971), while 'Mabo' (1993, tr. 8) celebrates the High Court's eventual recognition of native title in Australia (Australia 1992). 'Lonely Tree' (2000b, tr. 11) commemorates the last Gumatj banyan vine left standing in the vicinity of the Gove Peninsula bauxite plant, and in 'Gone is the Land' (2000b, tr. 12), Mandawuy reminisces about his early childhood, when his mother taught him to hunt the lands that were later lost to the mine. The fate of the 'Yirrkala Bark Petition', displayed behind glass in Australia's Parliament House, is lamented in 'Written on a Bark' (1999, tr. 9). Its opening lyrics evoke the heavy weight of Yolnu suffering in Australia's recent history: 'A long time ago, they stood proud and strong. Singing the land; touched the ground, signed the deed that was taken away in the name of a king. Can you heal the pain?' (verse 1).

\section{Hope for the future}

Music is integral to Yolnu life in Arnhem Land, and when Yolnu are born, they carry that special gift in their blood. They are automatically exposed to it. I grew up in a situation where there were only a handful of missionaries, so my exposure to song and dance was immense at Yirrkala. When I wasn't going to school there, my father and mother would take me out hunting, following the seasons. There was that balance to my education. My exposure to the Western way in the classroom, learning Western musics and adjusting to the meanings behind them made me want to switch them around. Using my Yolnu thinking, I combined the Western way with that of the Yolnu to make it possible for others to understand. (Yunupinu from Yunupinu and Corn 2005)

This article has explored expressions of classical Yolnu culture and values the music of Yothu Yindi, and Mandawuy Yunupinu's compositional intent in drawing on hereditary Yolnu performance traditions to assert the continuation of ancestral Yolnu agencies in the contemporary world. It has revealed the roots of Mandawuy's theories of biculturalism in his upbringing at Yirrkala and his work as a Yolnu educator, and how Yothu Yindi, with its bicultural blend of Yolnu and Balanda musicians and styles, reflected the balance and mutual respect between indigenous and new Australians that the band sought to engender in the world.

While 'Treaty' (Yothu Yindi 1991, tr. 2) became an influential anthem for the Aboriginal Reconciliation movement in Australia (Aboriginal and Torres Strait Islander Commission 2001), few who today see the 'Yirrkala Bark Petition' or the 'Barunga Statement' on display at Parliament House in Canberra will know of the tragedy suffered by Mandawuy's family as their legal struggle against the Gove Peninsula mine was ultimately defeated, with their most sacred rom trivialised and rejected by the Australian judiciary in the process. Yothu Yindi's music nonetheless asserts that Yolnu must continue to follow in the paths of their ancestors, and to keep on singing and 
dancing their rom regardless. This affirmation in the chorus of 'Hope' (1991, tr. 12) 'And we will sing and dance under the honey sun, forever and ever, day and day' is not a statement of desire, but one of duty. It remains the sacred responsibility of contemporary Yolnu to carry all that countless generations of their ancestors have provided 'into the future of another day' (Yothu Yindi 1991, tr. 7, verse 3).

Through its frequent references to traditional themes and materials, Yothu Yindi's music continually points local audiences 'back to culture' (1993, tr. 6); back to the ancestral values and practices that underpin Yolnu society. Its resetting of these themes and materials in the rock idiom demonstrated how durable traditional ideas could be contemporised for younger Yolnu audiences, and successfully draw their attention away from competing Anglophonic entertainments. This compositional approach has since become the accepted standard among many newer bands in Arnhem Land (Corn 2002) such as the highly successful Saltwater (1998, 2004; Yunupinu 2008), Nabarlek (1999, 2001, 2005, 2007) and Yilila (2005, 2006).

Finally, Yothu Yindi's music also demonstrated how the rock idiom could be commandeered to communicate durable traditional Yolnu ideas across cultures, and to encourage audiences worldwide to dream of a future Australia in which 'the waters will be one' (1991, tr. 2, verse 2). Like the 'Yirrkala Church Panels', the 'Yirrkala Bark Petition' and the 'Barunga Statement', Yothu Yindi is a deliberate step in an intergenerational continuum of Yolnu diplomacy across cultures. To echo Mandawuy's own words (Yunupinu from Yunupinu and Corn 2005), the continuing aim of this diplomatic effort is to 'make it possible for others to understand' why the Yolnu continue to struggle for formal recognition of their sovereignty in Australia, and why this is crucial both to their very cultural survival and to building a more equitable Australia for all.

\section{Endnotes}

1. The accepted conventions for Yolnu-Matha spellings are those of Zorc (1996).

2. All cited titles by artists from Arnhem Land are available from Skinnyfish Music (2008) with the exception of Yilila (2008).

3. Milkaynu Munungurr passed away in 2007. It is strictly against Yolnu law for forenames of deceased individuals to be spoken for some years (Keen 1994, p. 139). Please respect his family's wishes in this regard.

4. A dhuni' is a traditional 'burial shelter' made of timbre and leafy boughs where sacred bathi ('baskets') are hung to focus their ancestral power around the deceased.

5. In the most widely spoken Yolnu language, Dhuwal(a), suffixes differ between matha spoken by Dhuwa mala and matha spoken by Yirritja mala differ. Dhuwa leaders are therefore called liya-närra'mirr and Yirritja leaders liya-närra'mirri.

6. Gakal are also the leaders of chorus dancers in ceremonies. As highly proficient dancers, they are entrusted with handling important sacred artefacts such as bathi. Though translatable as 'power', likan is also a class a sacred name sung in dhuni' invocations by liya-närra'mirr(i) men to mark the passage of garma ceremonial actions with ancestral authority. Its literal translation is 'elbow' as the angles found in the repeating patterns of each mala's most sacred designs as the same as those made by dancers with their arms when accompanying invocations (Keen 1994, pp. 94-103).

7. Late in 2007, Peter Garrett was elected to the Australian House of Representatives as the Labour Member for Kingsford Smith, and became Federal Minister for the Environment, Heritage and the Arts.

\section{References}

Aboriginal and Torres Strait Islander Commission (ATSIC). 2001. 'Everybody's talking: Treaty', ATSIC News, February, p. 37

Australia. 1968. Northern Territory Supreme Court, no. 341, Milirrpum [Marika] and Others v. Nabalco Pty Ltd and the Commonwealth of Australia (Milirrpum v. Nabalco), Statement of Claim 
Australia. 1971. Milirrpum v. Nabalco, Judgement of Justice Blackburn, Federal Law Reports, 17, pp. 141-294

Australia. 1992. High Court of Australia, no. 23, Mabo and Others v. Queensland (Mabo v. Queensland) (no. 2), Judgement of Chief Justice Mason and Justice McHugh, Commonwealth Law Reports, 175, pp. 1-216

Bagshaw, G. 1998. 'Gapu dhulway, gapu maramba: conceptualisation and ownership of saltwater among the Burarra and Yan-Nhanu peoples of Northeast Arnhem Land', in Customary Marine Tenure in Australia, ed. N. Peterson and B. Rigsby (Sydney), pp. 154-77

Berndt, R., and Berndt, C. 1988. The World of the First Australians, 5th edn (Canberra)

Buku-Larrngay Mulka Centre. 1999. Saltwater (Sydney)

Christie, M. 1989. 'Literacy, genocide and the media', Aboriginal Child at School, 17/5, pp. 27-32

Cooke M. (ed.) 1996. Aboriginal Languages in Contemporary Contexts (Batchelor)

Corn, A. 2002. 'Burr-gi wargugu ngu-ninya rrawa: the Letterstick Band and hereditary ties to estate through song', Musicology Australia, 25, pp. 76-101

Corn, A. 2003. 'Outside the hollow log: the didjeridu, globalisation and socioeconomic contestation in Arnhem Land', Rural Society, 13, pp. 244-57

Corn, A. 2005. 'When the waters will be one: hereditary performance traditions and the Yolnu reinvention of post-Barunga intercultural discourses', Journal of Australian Studies, 84, pp. 15-30

Corn, A. 2007. 'To see their fathers' eyes: expressions of ancestry, fraternity and masculinity in the music of popular bands from Arnhem Land, Australia', in Oh Boy! Masculinities and Popular Music, ed. F. Jarman-Ivens (New York), pp. 77-99

Corn, A., with Gumbula, J. 2003. 'Djiliwirri ganha dhärranhana, wäna limurrungu', Australian Music Research, 7, pp. 55-66

Corn, A., with Gumbula, J. 2005. 'Ancestral precedent as creative inspiration', in The Power of Knowledge, the Resonance of Tradition, ed. G. Ward and A. Muckle (Canberra, AIATSIS), pp. 31-68

Corn, A., and Gumbula, N. 2004. 'Now Balanda say we lost our land in 1788: challenges to the recognition of Yolnu law in contemporary Australia', in Honour among Nations? Treaties and Agreements with Indigenous Peoples, ed. M. Langton et al. (Melbourne), pp. 101-14

Corn, A., and Gumbula, N. 2005. 'Ancestral precedent as creative inspiration: the influence of Soft Sands on popular song composition in Arnhem Land', in The Power of Knowledge, the Resonance of Tradition: Electronic Publication of Papers from the AIATSIS Conference 2001, ed. G. Ward and A. Muckle (Canberra), pp. 31-68

Corn, A., and Gumbula, N. 2006. 'Rom and the academy repositioned: binary models in Yolnu intellectual traditions and their application to wider inter-cultural dialogues', in Boundary Writing: An Exploration of Race, Culture and Gender Binaries in Contemporary Australia, ed. L. Russell (Honolulu), pp. 170-97

Corn, A., and Gumbula, N. 2007. 'Budutthun ratja wiyinymirri', Australian Aboriginal Studies, 2, pp. 116-27

Corn, A., with Yunupinu, M. 2001. Recorded interviews, 8 March and 26 May (Melbourne)

Corn, A., with Yunupinu, M. 2005. Ratification meetings, 13-29 September (Sydney-Melbourne)

Corn, A., with Yunupinu, M., Kellaway, S., and Marika, W. 2005. Ratification meetings, 30 April-2 May (Dhanaya)

Corn, A., with Yunupinu, M., and Marika, W. 2005. Ratification meetings with Mandawuy Yunupinu and Witiyana Marika, 25-30 April (Nyinyikay)

Deger, J. 2006. Shimmering Screens (Minneapolis)

Dunbar-Hall, P. 1997. 'Music and meaning: the Aboriginal rock album', Australian Aboriginal Studies, 15/1, pp. $38-47$

Dunbar-Hall, P., and Gibson, C. 2004. Deadly Sounds, Deadly Places: Contemporary Aboriginal Music in Australia (Sydney)

Dunlop, I. (dir.). 1970-1996. The Yirrkala Film Project, 22 films (Canberra)

Gondarra, D. 2001. 'Customary law', in Garma Festival 2001: yärra' Legal Forum (Darwin), pp. 15-20

Harris, S. 1990. Two Way Aboriginal Schooling (Canberra)

Hayward, P. 1993. 'Safe, exotic and somewhere else,' Perfect Beat, 1/2, pp. 33-41

Hayward, P. (ed.) 1992. From Pop to Punk to Postmodernism (Sydney)

Horton, D. (ed.) 1994. The Encyclopaedia of Aboriginal Australia (Canberra)

Keen, I. 1994. Knowledge and Secrecy in an Aboriginal Religion (Oxford)

Keen, I. 2000. 'A bundle of sticks: the debate over Yolnu clans', Journal of the Royal Anthropological Institute, 6, pp. 419-36

Knopoff, S. 1992. 'Yuta Manikay: juxtaposition of ancestral and contemporary elements in the performance of Yolnu clan songs', 'Yearbook for Traditional Music, 24, pp. 138-53

Knopoff, S. 1997. 'Yolnu', in The Oxford Companion to Australian Music, ed. W. Bebbington (Melbourne), pp. 602-3

Magowan, F. 1994. 'The land is our märr (essence), it stays forever', in Ethnicity, Identity and Music, ed. M. Stokes (Oxford), pp. 135-55

Magowan, F. 1996. 'Traditions of the mind or the music-video', Arena Journal, 7, pp. 99-110

Magowan, F. 2007. Melodies of Mourning (Santa Fe)

Magowan, F., and Neuenfeldt, K. (eds.) 2005. Landscapes of Indigenous Performance (Canberra)

Marika, M., et al. 1963. 'Yirrkala Petition to the House of Representatives' (Yirrkala)

Marika, R., Jurruwutthun, D., and White, L. 1989. 'Always together, yaka gäna', Convergence, 25/1, pp. 23-39

Marika, W., et al. 1962-1963. 'Yirrkala Church Panels' (Yirrkala) 
McIntosh, I. 1994. 'The dog and the myth maker: Makassans and Aborigines in northeast Arnhem Land', Australian Folklore, 9, pp. 77-81

McIntosh, I. 1996. 'Islam and Australia's Aborigines? A perspective from northeast Arnhem Land', Journal of Religious History, 20/1, pp. 53-77

McIntosh, I. 1997. 'Anthropology, self determination and Aboriginal belief in the Christian God', Oceania, 67, pp. 273-88

McIntosh, I. 2000. Aboriginal Reconciliation and the Dreaming: Warramiri Yolyu and Quest for Equality (Boston)

Mitchell, T. 1992. 'World music, indigenous music and music television in Australia', Perfect Beat, 1/1, pp. 1-16

Mitchell, T. 1993a. 'World music and the popular music industry', Ethnomusicology, 37, pp. 328-32

Mitchell, T. 1993b. Reply to 'Culture, custom and collaboration' by Lisa Nicol, Perfect Beat, 1/2, pp. 31-2

Morphy, H. 1991. Ancestral Connections (Chicago)

Morphy, H. 2008. Becoming Art: Exploring Cross-Cultural Categories (Oxford)

Mountford, C. 1956. Art, Myth and Symbolism (Melbourne)

Mundine, D. 1999. 'Saltwater' (Buku-Larrngay Mulka Centre), pp. 22-5

Neuenfeldt, K. 1993. 'Yothu Yindi and ganma', Journal of Australian Studies, 38, pp. 1-11

Neuenfeldt K. (ed.) 1997. The didjeridu: From Arnhem Land to the Internet (Sydney)

Nicol, L. 1993. 'Culture, custom and collaboration', Perfect Beat, 1/2, pp. 23-31

Skinnyfish Music. 2008. www.skinnyfishmusic.com.au, accessed 6 April 2008

Stubington, J. 2007. Singing the Land (Sydney)

Stubington, J., and Dunbar-Hall, P. 1994. 'Yothu Yindi's "Treaty"', Popular Music, 13/3, pp. 243-59

Tamisari, F. 1998. 'Body, vision and movement: in the footprints of the ancestors', Oceania, 68, pp. 249-70

Tamisari, F. 2000. 'Dancing the land', Writings on Dance, 20, pp. 30-45

Toner, P. 2000. 'Ideology, influence and innovation: the impact of Makassan contact on Yolnu music', Perfect Beat, 5/1, pp. 22-41

Williams, N. 1986. The Yolvu and Their Land (Canberra)

Yilila. 2008. www.yilila.com, accessed 6 April 2008

Yirrkala Community School Action Group. 1988. Towards a Ganma Curriculum in Yolnu Schools (Yirrkala)

Yothu Yindi Foundation. 2006. Garma Festival, www.garma.telstra.com, accessed 6 April 2008

Yunupinu, G., et al. 1988. 'Barunga Statement' (Barunga)

Yunupinu, M. 1994. 'Yothu Yindi', Race and Class, 35/4, pp. 114-20

Yunupinu, M., and Corn, A. 2005. 'Yothu Yindi: A legacy of hope', keynote address to the 28th National Conference of the Musicological Society of Australia, 28 September (Sydney)

Yunupinu, Y., and Dhamarrandji, D. 1997. 'My island home', in Our Land is Our Life, ed. G. Yunupinu (Brisbane), pp. 181-7

Zorc, R. 1996. Yolnu-Matha Dictionary (Batchelor)

\section{Discography}

Johnson, S. (dir.), Yolvu Boy. Palace Films, 22054SDW. 2000

Midnight Oil, Diesel and Dust. CBS, 460005. 1986

Nabarlek, Munwurrk (Bushfire). Skinnyfish Music. 1999

Nabarlek, Bininj Manborlh (Blackfella Road). Skinnyfish Music. 2001

Nabarlek, Live. Skinnyfish Music. 2005

Nabarlek, Manmoyi Radio. Manmoyi Music. 2007

No Fixed Address, From My Eyes. Mushroom, D19696. 1982

Saltwater Band, Gapu Damurruך'. Skinnyfish Music. 1998

Saltwater Band, Djarridjarri [sic Djärritjarri]. Skinnyfish Music. 2004

Wailers, Burnin'. Island, BM10001. 1973

Yilila, Manilamanila. 2005

Yilila, Aeroplane. 2006

Yothu Yindi, Homeland Movement. Mushroom, D19520. 1989

Yothu Yindi, Tribal Voice. Mushroom, D30602. 1991

Yothu Yindi, Diti Murru [sic Ditimurru]: The Videos. Mushroom, V81305. 1992a

Yothu Yindi, Tribal Voice, extended ed. Mushroom, TVD91017. 1992b

Yothu Yindi, Freedom. Mushroom, TVD93380. 1993

Yothu Yindi, Birrkuta [sic Birrkuda]: Wild Honey. Mushroom, TVD93461. 1996

Yothu Yindi, One Blood. Mushroom, MUSH332292. 1999

Yothu Yindi, Yothu Yindi Video Clip Compilation. Yothu Yindi. 2000a

Yothu Yindi, Garma. Mushroom, MUSH332822. 2000b

Yothu Yindi Foundation, Contemporary Masters Series, 6 albums. Yothu Yindi Foundation, YYF 1-6. 2001-2003

G. Yunupinu, Gurrumul. Skinnyfish Music. 2008 